\title{
Investigating the Effect of Total Quality Management Practices on Organizational Performance in the Jordanian Banking Sector
}

\author{
Rawan Al-Ettayyem ${ }^{1} \&$ Zu'bi M. F. Al-Zu'bi ${ }^{1}$ \\ ${ }^{1}$ School of Business, The University of Jordan, Amman, Jordan \\ Correspondence: Zu'bi M. F. Al-Zu’bi, School of Business, The University of Jordan, Amman, Jordan. E-mail: \\ z.alzubi@ju.edu.jo
}

Received: November 30, 2014

Accepted: January 4, $2015 \quad$ Online Published: February 25, 2015

doi:10.5539/ibr.v8n3p79

URL: http://dx.doi.org/10.5539/ibr.v8n3p79

\begin{abstract}
The aim of this study is to examine the effect of Total Quality Management (TQM) practices (customer satisfaction, education and training, continuous improvement, teamwork, and top management commitment) on organizational performance (financial and non-financial) in the Jordanian banking sector.

Research papers which are related to services are limited in Jordan. Since Jordanian economy is heavily dependent on the services sector, such research may enhance the quality of this sector.

The methodology is based on a questionnaire distributed to 11 commercial banks, and the statistical package for social sciences (SPSS) was used to analyse and examine the hypotheses. This research has indicated that TQM practices have a positive effect on organizational performance both financially and non-financially.
\end{abstract}

Keywords: banking sector, organizational performance, Total Quality Management (TQM)

\section{Introduction}

In recent years, measuring organizational performance has become essential for companies to survive, whether they are in the manufacturing or service sector. Globalization has brought unexpected changes to the economy, and because of this, all organizations are looking for strategies to increase performance and mechanisms to withstand any crisis, particularly in the banking sector. The banking sector is facing unstable financial times, related to liquidity, inflation, exchange rate, credit, loans, cash flow and interest rate, so banks need to establish procedures and tools in order to confront these challenges enhance their performance and survive through economic hardships.

The banking sector is the largest sector in the service industry that serves the needs of different categories of people. Currently, TQM has become the new method to reinforce competitive advantages and organizational performance; it is the core of a company's success (Ooi et al., 2011).

The main idea of this research is: Can the Jordanian banking sector utilizing of TQM practices to improve their performance? Answering this question will provide a deeper understanding of the dynamic role of all TQM practices.

Many banks in Jordan have a vested interest in implementing TQM practices. However, research efforts related to this field in Jordan are scarce; this study seeks to understand the relationship between TQM practices and organizational performance in the Jordanian banking sector. While TQM has been heavily researched in recent years, researchers have struggled to decide how to breakdown the concept of TQM into appropriate sub-categories. Through creating appropriate sub-hypothesis this paper will be able to provide a more thorough picture than before of how all the different aspects of TQM affects the success in the banking sector. This paper also fills an important hole in the literature by specifically addressing the banking sector in Jordan. This study will help managers working in developing economies understand how TQM may benefit their business.

\section{Literature Review}

\subsection{TQM Practices}

During the last couple of decades, a number of studies have shown that total quality management (TQM) has benefited organizations by improving quality of products and services, helping to provide superior quality products to their customers, and enhancing and increasing a firm's performance. (Hoang et al., 2010), Kaynak 
(2003, p. 206) stated that: "TQM is a holistic management philosophy that strives for continuous improvement in all functions of an organization, and it can be achieved." It is very essential for organizations to consider the common ties among service productivity, quality and innovation (Parasuraman, 2010). TQM has become one of the most important factors of today's vigorous competition (Almansour, 2012).

TQM practices in service firms have been discussed in many studies, but there are always disagreements as to 'how to best cut the TQM cake' into factors or elements (Samson \& Terziovski, 1999). Each firm relies on a set of practices depending on the nature of that firm as there are a variety of TQM practices and a diversity of dimensions (Bon \& Mustafa, 2013a).

Bon and Mustafa (2013b, p. 519) identified the following seven practices of TQM; top management leadership, employee involvement, employee empowerment, customer focus, training, information analysis, and continuous improvement.

Other studies such as Zehir et al. (2012, p. 275) focus on the eight dimensions of TQM; leadership management, employee management, customer focus, factual approach to decision making, supplier management, continual improvement, system approach to management and process management.

In this research, the TQM practices that were selected for banking sector are: top-management commitment, customer satisfaction, training and education, continuous improvement, and teamwork. These practices have been identified as the key practices of TQM in service industries, and in the promotion of service quality. (Sweis et al., 2013, p. 274).

\subsubsection{Customer Satisfaction}

Rai (2013) defined satisfaction as "a buyer's emotional or cognitive response post-subjective assessment and comparison of pre-purchase expectations and actual performance subsequent to the consumption of the product or service, meanwhile evaluating the costs incurred and benefits reaped in a specific purchase even or over time in course of transacting with an organization".

Most recent studies emphasize the importance of customer satisfaction, like (Asikhia, 2010; Kassim \& Abdullah, 2010), who showed that the customer satisfaction is a vital trend to develop the organizational performance, Fotopoulos and Psomas's (2010) study also reflects that customer focus and satisfaction are positively and significantly related to the performance of the organization, while Chen et al. (2012) confirmed that well-established relationship with customers can increase both financial and nonfinancial performance.

Dadfar et al. (2013) reveals that it is important to build a strong relationship with the customer and service provider in order to be able to have an efficient co-production together.

So, does focusing on the customer improve the organizational performance or not?

\subsubsection{Training and Education}

Employees are the most important asset in any organization, whether it has one employee or a hundred. Better employees will always lead to better performance. In order to cultivate good employees companies should educate their staff by training them in new skills and knowledge which will lead to a more efficient and effective workplace (Cervená, 2011). Globalization and radical change in technology require innovative ways of providing education and training programs for employees (Vargas \& Tian, 2013).

Training refers to a planned effort by a company to facilitate employees' learning of job-related competencies, including knowledge, skills, or behaviours that are critical for successful job performance (Mondy \& Mondy, 2013). Training and education make employees more productive and helps increase employee's skills and knowledge to increase job satisfaction (Gagnon et al., 2013).

If the bank improves the educational and training program for its employees, will this improve the bank's performance?

\subsubsection{Top Management Commitment}

The definition of commitment is "a force that binds an individual to a course of action of relevance to one or more targets" (Meyer \& Herscovitch, 2001).

Top management commitment plays a vital role in building trust with employees, and must go beyond adopting slogans of improving quality and become more involved in quality efforts at various planning and implementation and monitoring phases. Top managers must focus on developing people's skills and capacities through the engagement of employees in several kinds of training programs, which provide the organization with a skilful sales-force and marketing team (Jones \& Grimshaw, 2012). 
Top managers should involve all employees in the implementation and design stages in order to meet the expectations of stakeholders, customers, and to raise levels of quality and satisfaction (Pencarelli et al., 2013).

The managers must have profound knowledge of TQM, a willingness to actively participate and enthusiasm. They need clearly defined terms for good understanding of the work; otherwise employees may develop their own definitions which might lead to unfavourable outcomes for the organization and stakeholders (Sanzo \& ALvarez, 2012).

In conclusion the query is: what is the relationship between top management commitment and organizational performance?

\subsubsection{Team Work}

Doorewaard et al. (2002) define teamwork as a "process to fulfil the employee's need for control over their work environment". It holds a common task requiring interdependent work and action (Thompson, 2011). Subsequently teamwork is a set of behavioural skills working together to generate best outcomes (Hughes \& Jones, 2011).

Teamwork is an essential aspect for the success of the organization; it leads the organization to communicate with the goal and mission of the organization, encourages creativity, shares information, builds trust and openness and empowers employees (Griffin et al., 2001).

Salas et al. (2010) found that teamwork helps maintain competitive advantage in the face of challenges caused by several world events and also by international marketplaces.

So now we need to know if teamwork has a positive or negative impact on organizations.

\subsubsection{Continuous Improvement CI}

CI concept is widely used in many organizations worldwide. There are numerous definitions of continuous improvement, such as: Bessant et al. (2001) "an organization-wide process of focused and sustained incremental innovation." Gertsen (2001) describes CI as "an improvement process that is systematically applied, carried out in small steps, and to a large extent relies on employee participation", Similarly, Boer (2002) defines CI as planned, organized and systematic incremental changes that influence organizational performance.

CI is like an umbrella for a wide domain of tools and techniques to improve an organization's performance, such as Lean, Six Sigma, problem solving methodology, statistical process control SPC, control charts and cause and effect diagrams (Ehie \& Sheu, 2005). It's mostly applied to any management approach to improve the quality of the outcome.

Also, CI can be defined as the ongoing interaction between operations, innovation, learning that aims to achieving organizational cost and administrative effectiveness, efficiency and flexibility, (Davison \& Hyland, 2006). In addition the employees' creativity and knowledge are the basis for continuous improvement (Liker \& Hoseus, 2010).

TQM is mainly concerned with continuous improvement in all work, from high level strategic planning and decision-making, to detailed execution of work elements. The defects can be prevented, as it leads to continuously improving results of people, processes, and technology (Ijaz et al., 2012). The continuous improvement is a dynamic process, focus on improvement programs, services, materials and their relationship with the organization's customers, suppliers, competitors, and capital markets (Jagdeep \& Singh, 2013).

\section{So the question is: can continuous improvement reinforce organizational performance?}

\subsection{Organizational Performance}

Performance is "the results document the relationship between what organizations do in terms of quality management practices and the results they achieve in several types of outcomes" (NIST, 2010). Wheelen and Hunger (2010), in a hypercompetitive environment, organizations are increasingly seeking development, innovation and to improve the quality of the productlservice (Alam \& Yasin 2010). Promoting superior quality and innovation should be one of the most important priorities in any organization (Zeng et al., 2010).

\subsubsection{Balanced Scorecard Basics BSC}

The balanced scorecard is a strategic planning and management system that is used extensively in business, industry, government, and non-profit organizations worldwide to align business activities to the vision and strategy of the organization, improve internal and external communications, and monitor organization performance against strategic goals. As Kaplan and Norton (2003) mention, "Balanced Scorecards tell you the knowledge, skills and systems that your employees will need (learning and growth) to innovate and build the 
right strategic capabilities and efficiencies (internal processes) that deliver specific value to the market (customer) which will eventually lead to higher shareholder value (financial)".

\subsubsection{Six Sigma}

Six Sigma is one of the most effective problem solving methodologies for improving business and organizational performance. Other persons described Six Sigma as a disciplined and statistically based approach for improving product and process quality (Hahn et al., 2000). Also, Six Sigma refers to a business process that allows organizations to improve drastically their bottom line by designing and monitoring everyday business activities in ways that minimize waste and resources while increasing customer satisfaction (Harry \& Schroeder, 2000).

\subsubsection{TQM Practices and Banking Sector}

For long term survival organizations must adopt a broad, strong strategy that gives a sustainable competitive advantage and superior services that distinguish the organization from its competitors. Service is a kind of performance that is offered by one party to another (Kotler \& Keller, 2012). Many researchers support the role of TQM in the banking sector. (Lukasz, Skowron, \& Kristensen, 2012) found that the TQM has a positive relationship with customer satisfaction.

Goetsch and Davis, (2013) said that total quality management enhances the organization's strength to reduce the cost and improve the organization's chances of becoming a leader in a particular market. Al-Marri et al. (2007, p. 174) found it is essential for banking sector to improve profitability, expand the customer base and increase customer loyalty. Likewise SamanYapa (2012, pp. 505-517) recommends the best ways of utilizing TQM tools and techniques that will improve bank performance and service quality.

\section{Research Model and Hypotheses}

Based on the literature review, a framework is developed to discuss the relationships between TQM practices and organizational performance (financial and non-financial) in the Jordanian banking sector. In this framework, the independent variable is TQM practices and the dependent variable is organizational performance. Two main hypotheses and five sub-hypotheses for each main hypothesis are suggested to investigate theses relationship:

$\mathrm{H}_{1}$ : There is a positive relationship between TQM practices and organizational performance (financial) in the Jordanian banking sector at level $(\alpha \leq 0.05)$.

$\mathrm{H}_{1}$ a: There a positive relationship between customer satisfaction and organizational performance (financial) in the Jordanian banking sector at level $(\alpha \leq 0.05)$.

$\mathrm{H} 1 \mathrm{~b}$ : There is a positive relationship between training and education and organizational performance (financial) in the Jordanian banking sector at level $(\alpha \leq 0.05)$.

$\mathrm{H} 1 \mathrm{c}$ : There is a positive relationship between continuous improvement and organizational performance (financial) in the Jordanian banking sector at level $(\alpha \leq 0.05)$.

$\mathrm{H} 1 \mathrm{~d}$ : There is a positive relationship between teamwork and organizational performance (financial) in the Jordanian banking sector at level $(\alpha \leq 0.05)$.

$\mathrm{H} 1$ e: There is a positive relationship between top management commitment and organizational performance (financial) in the Jordanian banking sector at level $(\alpha \leq 0.05)$.

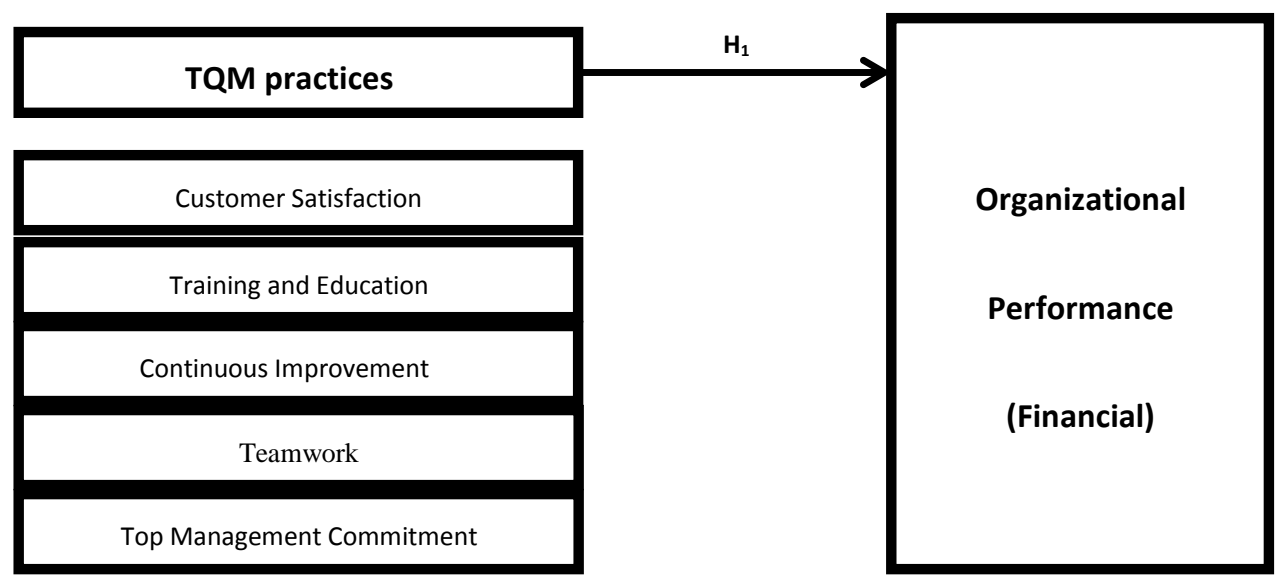

Figure 1. Study model (1) 
$\mathrm{H}_{2}$ : There is a positive relationship between TQM practices and organizational performance (non-financial) in the Jordanian banking sector at level $(\alpha \leq 0.05)$.

$\mathrm{H} 2$ a: There is a positive relationship between customer satisfaction and organizational performance (non-financial) in the Jordanian banking sector at level $(\alpha \leq 0.05)$.

$\mathrm{H} 2 \mathrm{~b}$ : There is a positive relationship between training and education and organizational performance (non-financial) in the Jordanian banking sector at level $(\alpha \leq 0.05)$.

$\mathrm{H} 2 \mathrm{c}$ : There is a positive relationship between continuous improvement and organizational performance (non-financial) in the Jordanian banking sector at level $(\alpha \leq 0.05)$.

$\mathrm{H} 2 \mathrm{~d}$ : There is a positive relationship between teamwork and organizational performance (non-financial) in the Jordanian banking sector at level $(\alpha \leq 0.05)$.

$\mathrm{H} 1$ e: There is a positive relationship between top management commitment and organizational performance (non-financial) in the Jordanian banking sector at level $(\alpha \leq 0.05)$.

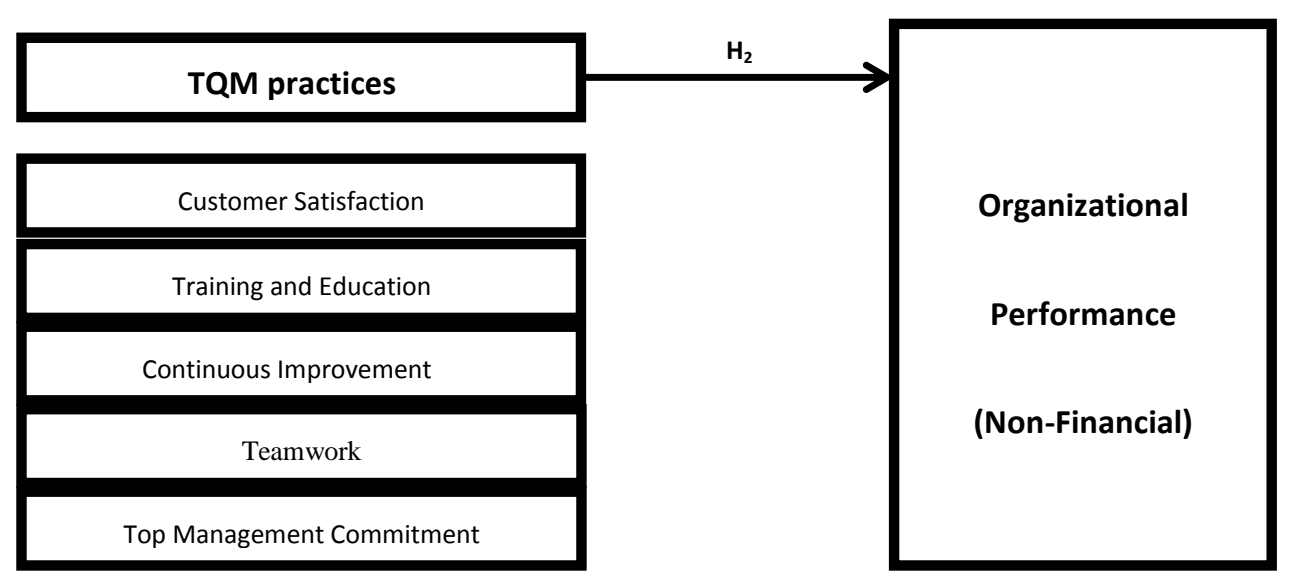

Figure 2. Study model (2)

\section{Research Methodology}

\subsection{Population, Sample and Data Collection}

The population of this study is the Jordanian banking sector, specifically commercial banks, as we focus on several departments in banks that have an effect on the study variables. The researcher developed a questionnaire after reviewing various references to serve the research purpose.

The researcher posted (250) questionnaires distributed randomly (by hand) to11commercial banks in Jordan. Only (230) were usable questionnaires. Twenty questionnaires were invalid for analysis and were excluded, so the total response approximately was $(92 \%)$. The researcher used a five - points scale in which 1=strongly agree, $2=$ agree, $3=$ neither agree nor disagree, $4=$ disagree, $5=$ strongly disagree.

\subsection{Reliability and Validity}

Validity refers to the accuracy of an assessment, the ability of a scale or measuring instrument to measure what it is intended to measure. It allows the researchers to determine if the items on an assessment target their goal or not, after preliminary designing of the questionnaire, the related questions have been studied in several steps, and examined from the point of being understandable, relevant to the test's objective and omission of the irrelevant questions through consulting sophisticated people and experts as well as taking comments from the advising professors, the questionnaire was valid enough as for the contents after effecting the required modifications.

Reliability is the degree that indicates if the dimension is free from accidental errors and offers constant data, therefore yielding consistent results.

Reliability was measured by using cronbach alpha that determine the inter correlations between items, the closer cronbach alpha is to 1 , the higher the internal consistency, and the research tool constructs are reliable (Sekaran, 2013). For this study the result is shown in Table 1. 
Table 1. Reliability statistic

\begin{tabular}{llc}
\hline \multicolumn{1}{c}{ Variables } & Reliability Statistic & Cronbach's alpha value \\
\hline TQM practices & Customer satisfaction & 0.825 \\
& Training and education & 0.832 \\
& Continuous improvement & 0.819 \\
& Teamwork & 0.820 \\
& Top management commitment & 0.777 \\
Organizational performance & Organizational performance (financial) & 0.901 \\
& Organizational performance (non-financial) & 0.865 \\
\hline & Reliability for all variables & 0.916 \\
\hline
\end{tabular}

\section{Analysis and Results}

\subsection{Factor Analysis}

Factor analysis for each measurement scale was performed to ensure that the scales were reliable indicators of their constructs, and factor analysis was carried out with principle of components analysis as the extraction method.

Table 2. Factor loading

\begin{tabular}{|c|c|}
\hline F1 Customer satisfaction & Factor Loading \\
\hline customer satisfaction Q1 & .846 \\
\hline customer satisfaction Q2 & .795 \\
\hline customer satisfaction Q3 & .807 \\
\hline customer satisfaction Q4 & .803 \\
\hline F2 Education \& Training & Factor Loading \\
\hline Education \& Training Q1 & .858 \\
\hline Education \& Training Q2 & .895 \\
\hline Education \& Training Q3 & .847 \\
\hline F3 Continuous Improvement & Factor Loading \\
\hline Continuous Improvement Q1 & .822 \\
\hline Continuous ImprovementQ2 & .857 \\
\hline Continuous Improvement Q3 & .842 \\
\hline F4 Teamwork & Factor Loading \\
\hline Teamwork Q1 & .839 \\
\hline Teamwork Q2 & .883 \\
\hline Teamwork Q3 & .850 \\
\hline F4 top management commitment & Factor Loading \\
\hline Top Management Commitment Q1 & .837 \\
\hline Top Management Commitment Q2 & .885 \\
\hline Top Management Commitment Q3 & .779 \\
\hline F1 Organizational performance (financial) & Factor Loading \\
\hline O.P. (F). Q1 & .867 \\
\hline O.P. (F). Q2 & .882 \\
\hline O.P. (F). Q3 & .879 \\
\hline O.P. (F). Q4 & .886 \\
\hline
\end{tabular}




\begin{tabular}{cc}
\hline F2 Organizational performance (non-financial) & Factor Loading \\
\hline O.P.(non.f) Q2 & .756 \\
O.P.(non.f) Q3 & .799 \\
O.P.(non.f) Q4 & .818 \\
O.P.(non.f) Q6 & .798 \\
O.P.(non.f) Q7 & .776 \\
\hline
\end{tabular}

Factor analysis above shows that all of group questions are explained by one variable per group which is the ideal form. It has been found that all factors have high correlation with variables, which means that the instrument of variable is valid.

The KMO statistic is a measure of sampling adequacy. This measure varies between 0 and 1 , and values closer to 1 are better.

Table 3. KMO and Bartlett's test

\begin{tabular}{lcc}
\hline \multicolumn{3}{c}{ KMO and Bartlett's Test } \\
\hline \multicolumn{2}{c}{ Kaiser-Meyer-Olkin Measure of Sampling Adequacy. } & .892 \\
\hline Bartlett's Test of Sphericity & Approx. Chi-Square & 781.349 \\
& Df & 21 \\
& Sig. & .000 \\
\hline
\end{tabular}

KMO measure of sampling adequacy and Bartlett's test of Sphericity are shown in this table. These results meet criteria and support use of factor analysis for this data as $\mathrm{KMO}=.892$, the degree of common variance is "Meritorious" bordering on "Marvellous".

Also in this data the Bartlett's test is highly significant sig $=.000<.05$, and therefore factor analysis is appropriate.

\subsection{Hypotheses Testing}

In order to test hypotheses, two main hypotheses have been formulated and tested by SPSS; the researcher used Simple Linear and Multiple Regression analysis to test the research hypotheses.

\subsubsection{First Main Hypothesis}

$\mathrm{H}_{1}$ : There is a positive relationship between TQM Practices and Organizational Performance (Financial) in the Jordanian banking sector at level $\boldsymbol{\alpha}=\mathbf{0 . 0 5}$.

Table 4. ANOVA for regression for first main hypothesis

\begin{tabular}{|c|c|c|c|c|c|c|c|c|}
\hline & Sum of Squares & Df & Mean Square & F calculated & F tabulated & Sig. & $\mathrm{R}$ & $\mathrm{R}^{2}$ Square \\
\hline Regression & 59.897 & 8 & 7.487 & 19.042 & 1.9384 & .000 & & \\
\hline Residual & 86.897 & 221 & .393 & & & & & \\
\hline Total & 146.793 & 229 & & & & & 0.639 & 0.408 \\
\hline
\end{tabular}

In Table 4, the F calculated (19.042) is greater than F tabulated (1.9384). Therefore; the null hypothesis is rejected and the alternative is accepted, with significant value $=.000<0.005$, that indicate there is a positive relationship between the independent variable TQM and dependent variables organizational performance (financial) at $\alpha=0.05$ level.

As appeared in this Table, $\mathrm{R}$ value $=(0.639)$, which refers to coefficient of correlation of the independent variable (TQM practices) and the dependent variable (financial performance of the organization).

Whereas, the coefficient of determination $\mathrm{R}^{2}=(0.408)$ means that the independent variable (TQM practices) explains $(40.8 \%)$ of the dependent variable (organizational performance, financial). 
Table 5. Regression coefficient for first main hypothesis

\begin{tabular}{|c|c|c|c|c|}
\hline \multirow[b]{2}{*}{ Model } & \multicolumn{2}{|c|}{ Unstandardized Coefficients } & \multirow{2}{*}{$\frac{\text { Standardized Coefficients }}{\text { Beta }}$} & \multirow[b]{2}{*}{ Sig. } \\
\hline & $\mathrm{B}$ & Std. Error & & \\
\hline (Constant) & .412 & .290 & & .157 \\
\hline Customer satisfaction & .245 & .073 & .227 & .001 \\
\hline Education \& training & -.046 & .080 & -.043 & .567 \\
\hline Continuous improvement & .340 & .087 & .313 & .000 \\
\hline Teamwork & .005 & .068 & .005 & .946 \\
\hline Top management commitment & .266 & .076 & .258 & .001 \\
\hline
\end{tabular}

$>\mathrm{H}_{1}$ a: There is a positive relationship between Customer Satisfaction and Organizational Performance (Financial) in the Jordanian banking sector at level $\alpha=0.05$.

$>\mathrm{H}_{1}$ b: There is a negative relationship between Education and Training and Organizational Performance (Financial) in the Jordanian banking sector at level $\alpha=0.05$.

$>\mathrm{H}_{1} \mathrm{c}$ : There is a positive relationship between Continuous Improvement and Organizational Performance (Financial) in the Jordanian banking sector at level $\alpha=0.05$.

$>\mathrm{H}_{1} \mathrm{~d}$ : There is a positive relationship between Teamwork and Organizational Performance (Financial) in the Jordanian banking sector at level $\alpha=0.05$.

$>$ H1e: There is a positive relationship between Top Management Commitment and Organizational Performance (Financial) in the Jordanian banking sector at level $\alpha=0.05$.

\subsubsection{Second Main Hypothesis}

$\mathrm{H}_{2}$ : There is positive relationship between TQM Practices and Organizational Performance (Non-Financial) in the Jordanian banking sector at level $\boldsymbol{\alpha}=\mathbf{0 . 0 5}$.

Table 6. ANOVA for regression for second main hypothesis

\begin{tabular}{ccccccccc}
\hline & Sum of Squares & Df & Mean Square & F calculated & F tabulated & Sig. & R & R2 Square \\
\hline Regression & 53.429 & 8 & 6.679 & 30.961 & 1.9384 & .000 & & \\
Residual & 47.673 & 221 & .216 & & & & & 0.727 \\
Total & 101.102 & 229 & & & & & 0.528 \\
\hline
\end{tabular}

According to Table 6, the F calculated (30.961) is greater than F tabulated (1.9384). Therefore, the null hypothesis is rejected if calculated is greater than tabulated, with sig $.000<0.005$, that indicates there is a positive relationship between the independent (TQM Practices) and dependent (Organizational Performance, non-financial) variables at $\alpha=0.05$.

Table 5 shows $\mathrm{R}$ value $(0.727)$ which refers to correlation of the independent variable (TQM practices) and the dependent variable (non-financial performance of the organization).

Whereas, the coefficient determination $\mathrm{R}^{2}=(0.528)$ means that the independent variable (TQM practices) explains $(52.8 \%)$ of the dependent variable (organizational performance, non-financial).

Table 9. Regression coefficient for second main hypothesis

\begin{tabular}{ccccc}
\hline & \multicolumn{2}{c}{ Unstandardized Coefficients } & Standardized Coefficients & \multirow{2}{*}{ Sig. } \\
\cline { 2 - 4 } Model & $\mathrm{B}$ & Std. Error & Beta & .000 \\
(Constant) & .840 & .215 & & .000 \\
Customer satisfaction & .209 & .054 & .234 & .008 \\
Education \&Training & .159 & .059 & .181 & .000 \\
Continuous improvement & .236 & .064 & .262 & .638 \\
Teamwork & -.024 & .051 & -.029 & .001 \\
Top management commitment & .182 & .056 & .212 & \\
\hline
\end{tabular}


$>$ H2a: There is a positive relationship between Customer Satisfaction and Organizational Performance (Non-Financial) in the Jordanian banking sector at level $\alpha=0.05$.

$>$ H2b: There is a positive relationship between Education and Training and Organizational Performance (Non-Financial) in the Jordanian banking sector at level $\alpha=0.05$.

$>\mathrm{H} 2 \mathrm{c}$ : There is a positive relationship between Continuous Improvement and Organizational Performance (Non-Financial) in the Jordanian banking sector at level $\alpha=0.05$.

$>\mathrm{H} 2 \mathrm{~d}$ : There is a positive relationship between Teamwork and Organizational Performance (Non-Financial) in the Jordanian banking sector at level $\alpha=0.05$.

$>$ H2e: There is a negative relationship between Teamwork and Organizational Performance (Non-Financial) in the Jordanian banking sector at level $\alpha=0.05$.

\section{Discussion and Conclusions}

The purpose of this paper was to study the relationship between TQM practices and organizational performance in the Jordanian banking sector. The results show that there is a positive relationship between TQM practices and organizational performance (financial and non-financial) in the Jordanian banking sector, this result is supported by (Hoang et al., 2010; Fotopoulos \& Psomas's, 2010; Goetsch \& Davis, 2013; Sweis et al., 2013).

Also, the research results show that there is a positive relationship between (customer satisfaction, continuous improvement, teamwork, top management commitment) and organizational performance (financial) in the Jordanian banking sector, this result is supported by Chen et al. (2012).

So, it is very essential to utilize these practices effectively in the Jordanian banking sector. On the other hand, there is a negative relationship between education and training and organizational performance (financial) that should not apply in banks that need to increase their financial performance.

Likewise, there is a positive relationship between (customer satisfaction, education and training, continuous improvement, top management commitment) and organizational performance (non-financial) in the Jordanian banking sector, this result is contrary with: (Ooi et al., 2010), but there is a negative relationship between teamwork and the organizational performance (non-financial).

The practical implications of the research are very important means for Jordanian banking sector for revealing information about TQM practices as well as organizational performance financial and non-financial, In addition, the results of this study reveal the relationship between the TQM practices and the organizational performance.

It's interesting that one strong predictor of performance was continuous improvement which is considered one of the main aspects of the TQM philosophy.

This result is consistent with Joiner (2006, p. 26), who mentions that: "One of the central tenets of effective TQM implementation is employees' commitment to continuous improvement of processes".

Therefore we suggest that banks be more concerned with TQM practices that could increase the organizational performance whether it's financial or nonfinancial, It has been from the research results that the most important TQM practices on organizational performance is the continuous improvement, we recommend to develop suitable plan and implemented to the fullest, motivate their employees to innovate and create new services which distinguish banks from others. We also recommend investigating the obstacles to TQM implementation, and implementing a study on other sectors or industries.

\section{References}

Abolarin, A. A., Abdullahi, O., Adedipe, T. S., \& Abdulrahman. (2013). Impact of top management commitment on implementation of total quality management in an organization. The Pacific Journal of Science and Technology, 14(2), 263-267.

Alam, S., \& Yasin, N. M. (2010). The antecedents of online brand trust: Malaysian evidence. Journal of Business Economics and Management, 11(2), 210-226. http://dx.doi.org/10.3846/jbem.2010.10

Almansour, Y. M. (2012). The impact of total quality management components on small and medium enterprises, financial performance in Jordan. Journal of Arts, Science and Commerce, 3(1), 87-91.

Al-Marri, K., Ahmed, A. M. M. B., \& Zairi, M. (2007). Excellence in service: An empirical study of the UAE banking sector. International Journal of Quality and Reliability Management, 24(2), 164-176. http://dx.doi.org/10.1108/02656710710722275

Asikhia, O. (2010). Customer orientation and firm performance among Nigerian small and medium scale 
businesses. International Journal of Marketing Studies, 2(1), 197-205. http://dx.doi.org/10.5539/ijms.v2n1p197

Bessant, J., Caffyn, S., \& Gallagher, M. (2001). An evolutionary model of continuous improvement behavior. Technovation Journal, 21(3), 67-77. http://dx.doi.org/10.1016/S0166-4972(00)00023-7

Boer, H. (2002). Continuous innovation seminar. Presented at University of Western Sydney: Campbell town.

Bon, A., \& Mustafa, E. (2013). Impact of total quality management on innovation in service organizations: Literature review and new conceptual framework. Procedia Engineering, 53(1), 516-529. http://dx.doi.org/10.1016/j.proeng.2013.02.067

Cervená, K. (2011). Effectiveness of education in the Slovak Republic. Paper presented at the Humanization of education at technical universities scientific papers proceeding, Bratislava.

Chen, H., Liu, J. Y., Sheu, T. S., \& Yang, M. (2012). The impact of financial services quality and fairness on customer satisfaction. Managing Service $\quad$ Quality, 22(4), 399-421. http://dx.doi.org/10.1108/09604521211253496

Dadfar, H., Staffan, B., Sedigheh, S., \& Ebadzadeh, S. (2013). Customer involvement in service production, delivery and quality. International Journal of Quality and Service Sciences, 5(1), 46-65. http://dx.doi.org/10.1108/17566691311316248

Davison, G., \& Hyland, P. (2006). Continuous innovation in a complex and dynamic environment: The case of the Australian health service. International Journal of Technology Management and Sustainable Development, 5(1), 41-59. http://dx.doi.org/10.1386/ijtm.5.1.41/1

Doorewaard, H., Van Hootegem, G., \& Huys, R. (2002). Team responsibility structure and team performance. Personnel Review, 31(3), 356-370. http://dx.doi.org/10.1108/00483480210422750

Ehie, I., \& Sheu, C. (2005). Integrating six sigma and theory of constraints for continuous improvement: A case study. Journal of Manufacturing Technology Management, 16(5), 542-553. http://dx.doi.org/10.1108/17410380510600518

Fotopoulos, C. V., \& Psomas, E. L. (2010). The structural relationships between total quality management factors and organizational performance. The TQM Journal, 22(5), 539-552. http://dx.doi.org/10.1108/17542731011072874

Gagnon, Marie-Eve, Smith, \& Michael. (2013). The effects of a training levy on training characteristics and outcomes: The case of Quebec. Industrial Relations Journal, 68, 120-141. http://dx.doi.org/10.7202/1014744ar

Gertsen, F. (2001). How continuous improvement evolves as companies gain experience. International Journal of Technology Management, 22(4), 303-326. http://dx.doi.org/10.1504/IJTM.2001.002966

Goetsch, D. L., \& Davis, S. (2013). Quality management for organizational excellence: Introduction to total quality (7th ed.). Boston: Pearson.

Griffin, M. A., Patterson, M. G., \& West, M. A. (2001). Job satisfaction and teamwork: The role of supervisor support. Journal of Organizational Behavior, 22(5), 537-550. http://dx.doi.org/10.1002/job.101

Hahn, G. J., Doganaksoy, N., \& Hoerl, R. (2000). The evolution of Six Sigma. Quality Engineering, 12(3), 317-26. http://dx.doi.org/10.1080/08982110008962595

Harry, M. J., \& Schroeder, R. (2000). Six sigma: The breakthrough management strategy revolutionizing the world's top corporations. New York: Doubleday. http://dx.doi.org/10.1198/tech.2001.s622

Hoang, D. T., Igel, B., \& Laosirihongthong, T. (2010). Total quality management (TQM) strategy and organizational characteristics: Evidence from a recent WTO member. Total Quality Management, 21(9), 931-951. http://dx.doi.org/10.1080/14783363.2010.487680

Hughes, R. L., \& Jones, S. K. (2011). Developing and assessing college student teamwork skills. New Directions for Institutional Research, 149, 53-64. http://dx.doi.org/10.1002/ir.380

Ijaz, A. K., \& Irfan, S. M. (2012). Internal customer job satisfaction and role of TQM practices. Far East Journal of Psychology and Business, 6(1), 1-14.

Jagdeep, S., \& Singh, H. (2013). Continuous improvement strategies: An overview. Journal of Operations Management, 12(1). 
Joiner, T. (2006). Total quality management and performance: The role of organization support and co-worker support. International Journal of Quality and Reliability Management, 24(6), 617-627. http://dx.doi.org/10.1108/02656710710757808

Jones, B., \& Grimshaw, D. (2012). Training and skills to improve innovation in firms. Manchester.

Kaplan, R. S., \& Norton, D. P. (2003). Strategy maps. Boston: HBS Press.

Kassim, N., \& Abdullah, N. A. (2010). The effect of perceived service quality dimensions on customer satisfaction, trust, and loyalty in e-commerce settings: Across cultural analysis. Asia Pacific Journal of Marketing and Logistics, 22(3), 351-371. http://dx.doi.org/10.1108/13555851011062269

Kaynak, H. (2003). The Relationship between total quality management practices and their effects on firm $\begin{array}{llll}\text { performance. Journal of } & \text { Operations }\end{array}$ http://dx.doi.org/10.1016/S0272-6963(03)00004-4

Kotler, P., \& Keller, K. L. (2012). Marketing management (14th ed.). Upper Saddle River, New Jersey: Pearson Education, Inc.

Liker, J. K., \& Hoseus, M. (2010). Human resource development in Toyota culture. International Journal of Human Resources Development and Management, 10(1), 34-50. http://dx.doi.org/10.1504/IJHRDM.2010.029445

Lukasz, S., \& Kristensen, K. (2012). The impact of the recent banking crisis on customer loyalty in the banking sector: Developing versus developed countries. The TQM Journal, 24(6). http://dx.doi.org/10.1108/17542731211270052

Meyer, J. P., \& Herscovitch, L. (2001). Commitment in the workplace: Toward a general model. Human Resource Management Review, 11(3), 299-326. http://dx.doi.org/10.1016/S1053-4822(00)00053-X

Mondy, R. W., \& Mondy, J. B. (2013). Human resource management (10th ed.). Boston: Pearson.

NIST. (2010). National institute of standards and technology: The 2009-2010. Criteria for Performance Excellence.

Ooi, K. B., Binshan, L., Boon-In, T., \& Yee-Loong, C. (2011). Are TQM practices supporting customer satisfaction and service quality? Journal of Services Marketing, 25(6). http://dx.doi.org/10.1108/08876041111161005

Parasuraman, A. (2010). Service productivity, quality and innovation. International Journal of Quality and Service Sciences, 2(3), 277-286. http://dx.doi.org/10.1108/17566691011090026

Pencarelli, T., Splendiani, S., \& Cini, D. (2013). Quality and value in university services. International Journal of Quality and Service Sciences, 5(2), 140-153. http://dx.doi.org/10.1108/IJQSS-03-2013-0014

Rai, A. K. (2013). Customer relationship management: Concepts and cases (2nd ed.). New Delhi: PHI Learning.

Salas, E., Cooke, N., \& Groman, J. (2010). The science of team performance: Progress and the need for more. Human Factors, 52(2), 344-346. http://dx.doi.org/10.1177/0018720810374614

Saman, Y. (2012). Total quality management in Sri Lankan service organizations. The TQM Journal, 24(6), 505-517. http://dx.doi.org/10.1108/17542731211270070

Samson, D., \& Terziovski, M. (1999). The relationship between total quality management practices and operational performance. Journal of Operations Management, 17(4), 393-409. http://dx.doi.org/10.1016/S0272-6963(98)00046-1

Sanzo, M. J., \& Lvarez, L. I. (2012). Perceptions of top management commitment to innovation and R\&D-marketing relationship effectiveness: Do they affect CSR? Annals of Public and Cooperative Economics, 83(3), 383-405. http://dx.doi.org/10.1111/j.1467-8292.2012.00468.x

Sekaran, U., \& Bougie, R. (2013). Research methods for business: A skill building approach (6th ed.). USA: HognWiely and Sons Inc.

Sweis, R. J., Al-Mansour, A., Tarawneh, M., \& Al-Dweik, G. (2013). The impact of total quality management practices on employee empowerment in the healthcare sector in Saudi Arabia: A study of King Khalid Hospital. International Journal of Productivity and Quality Management, 12(3), 271-286. http://dx.doi.org/10.1504/IJPQM.2013.056149

Thompson, L. L. (2011). Making the team: A guide for managers (4th ed.). Upper Saddle River, NJ: 
Pearson-Prentice Hall.

Vargas, N., \& Tian, X. (2013). E-learning: Much more than a matter of technology. International Journal of E-Education, E-Business, E-Management and E-Learning, 3(3), 277. http://dx.doi.org/10.7763/IJEEEE.2013.V3.240

Wheelen, T. L., \& Hunger, D. (2010). Strategic management and business policy (12th ed.). New York: Pearson Publishing Inc.

Zehir, C., Ertosun, Ö., Zehir, S., \& Müceldilli, B. (2012). Total quality management practices' effects on quality performance and innovative performance. Procedia Engineering, 41, 273-280.

Zeng, S. X., Xie, X. M., \& Tam, C. M. (2010). Relationship between cooperation networks and innovation performance of SMEs. Tech novation, 30, 181-194. http://dx.doi.org/10.1016/j.technovation.2009.08.003

\section{Copyrights}

Copyright for this article is retained by the author(s), with first publication rights granted to the journal.

This is an open-access article distributed under the terms and conditions of the Creative Commons Attribution license (http://creativecommons.org/licenses/by/3.0/). 